\title{
Synthesis of Cu Doped ZnO Nanoparticles: Crystallographic, Optical, FTIR, Morphological and Photocatalytic Study
}

\author{
P. K. Labhane' ${ }^{1}$, V. R. Huse ${ }^{1}$, L. B. Patle ${ }^{1}$, A. L. Chaudhari ${ }^{1}$, G. H. Sonawane ${ }^{2 *}$ \\ ${ }^{1}$ MGSM's Arts, Science and Commerce College, Chopda, India \\ ${ }^{2}$ Kisan Arts, Commerce and Science College, Parola, India \\ Email: ${ }^{\text {drgunvantsonawane@gmail.com }}$
}

Received 24 March 2015; accepted 22 June 2015; published 25 June 2015

Copyright @ 2015 by authors and Scientific Research Publishing Inc.

This work is licensed under the Creative Commons Attribution International License (CC BY). http://creativecommons.org/licenses/by/4.0/

(c) (i) Open Access

\section{Abstract}

Nanoparticles of $\mathrm{Zn}_{1-\mathrm{x}} \mathrm{Cu}_{\mathrm{x}} \mathrm{O}$ system with nominal compositions $\mathrm{x}=0.0,0.01,0.02$ and 0.03 were prepared by co-precipitation method at room temperature. Structural, morphological, optical and chemical species of grown crystals were investigated by X-ray diffraction (XRD) technique, Scanning Electron Microscopy (SEM), UV-visible and FTIR spectroscopy, respectively. XRD analysis confirms that all samples have hexagonal structure with no impurity phases which suggest that $\mathrm{Cu}$ ion successfully incorporated into the regular $\mathrm{ZnO}$ crystal structure. The lattice parameters, volume of unit cell, $X$-ray density, atomic packing fraction, c/a ratio, and grain size were calculated from XRD pattern of pure and $\mathrm{Cu}$ doped $\mathrm{ZnO}$ samples and it was found that the grain size was in the range of $23 \mathrm{~nm}$ to $29 \mathrm{~nm}$. The strain in pure and $\mathrm{Cu}$ doped $\mathrm{ZnO}$ samples was calculated by $\mathrm{W}$-H analysis. Optical properties of $\mathrm{Zn}_{1-\mathrm{x}} \mathrm{Cu}_{\mathrm{x}} \mathrm{O}$ samples were studied by using $\mathrm{UV}$-vis spectrophotometer. Optical absorption spectra show that the band gap decreases with increasing Cu contents. The functional group and chemical interactions of $\mathrm{Zn}_{1-\mathrm{x}} \mathrm{Cu}_{\mathrm{x}} \mathrm{O}$ samples were also determined at various peaks using FTIR data and observed that the functional groups corresponding to the $\mathrm{Zn}-\mathrm{O}$ bands in the samples. The photocatalytic activities of the samples were investigated by oxidation of methylene blue under UV light illumination in batch reactor. The scavenger study was carried out to find out main reactive species responsible for the degradation of dyes.

\section{Keywords}

ZnO, Nanostructure, Bandgap, Photocatalytic Activity, Scavenger Study

\footnotetext{
${ }^{*}$ Corresponding author.

How to cite this paper: Labhane, P.K., Huse, V.R., Patle, L.B., Chaudhari, A.L. and Sonawane, G.H. (2015) Synthesis of Cu Doped ZnO Nanoparticles: Crystallographic, Optical, FTIR, Morphological and Photocatalytic Study. Journal of Materials Science and Chemical Engineering, 3, 39-51. http://dx.doi.org/10.4236/msce.2015.37005
} 


\section{Introduction}

With great ability to manipulate structure of the materials on the level of individual atoms and molecules, the nanotechnology is a promising highly interdisciplinary field. The unique optical and electrical properties of $\mathrm{ZnO}$ nanomaterial such as wide band gap of $3.37 \mathrm{eV}$, large exciton binding energy of $60 \mathrm{meV}$ and high electron mobility at room temperature make it suitable for new application and devices. Nanostructures ZnO have many potential application in photocatalysis [1] [2], solar cell [3] [4], gas sensors [5] [6], fuel cells [7], photovoltaics [8], antibacterial action [9] and so on. Due to its inexpensiveness, nontoxic and environmentally safe, it has attracted more attention over last few years. Recently, modified $\mathrm{ZnO}$ was prepared by doping with transition metals such as $\mathrm{Ag}$ [10], $\mathrm{Mn}$ [11], Fe [12], $\mathrm{Co}$ [13], $\mathrm{Cr}$ [14], $\mathrm{Al}$ [15] and Pd [16]. The results of these transition metals doped $\mathrm{ZnO}$ show that the optical, magnetic and electrical properties changed with the change in concentration of transition metal. Electronic conductivity of $\mathrm{Cu}$ is very high and it is cheap and highly available on Earth's crust and so it is important metal for doping [17]. The doping of $\mathrm{Cu}$ in $\mathrm{ZnO}$ is expected to modify absorption, and other physical or chemical properties of $\mathrm{ZnO}$ [18] [19].

There has been increasing interest in environmental purification by heterogeneous photocatalysis using semiconductor. Heterogeneous photocatalysis is an effective method to degrade a large number of organic and inorganic contaminants in waste water. The surface area and surface defects are important parameters in photocatalytic activity of semiconductor metal oxide. Several metal oxides have been used as photocatalyst such as $\mathrm{TiO}_{2}$, $\mathrm{Nb}_{2} \mathrm{O}_{5}, \mathrm{Cu}_{2} \mathrm{O}$, and $\mathrm{ZrO}_{2}$ [20]-[23]. $\mathrm{ZnO}$ nanoparticle is the most promising catalyst for the degradation of organic pollutants because of its high surface activity, crystalline size, morphologies and textures [24]. The initial step in $\mathrm{ZnO}$-mediated photocatalysis degradation is proposed to involve the generation of an electron and hole $\left(\mathrm{e}^{-} / \mathrm{h}^{+}\right)$ pair. In aqueous solution valence band holes produce hydroxyl radicals $(\cdot \mathrm{OH})$ and conduction band electrons produce superoxide radical anion $\left(\mathrm{O}_{2}^{-}\right)$. These radicals are the oxidizing species in the photocatalytic oxidation processes, among which the hydroxyl radical is recognized to be the most powerful oxidizing species and can attack organic pollutants present at or near the surface of photocatalyst [25].

Doping of photocatalyst with metal ions creates local energy levels within the band gap of the photocatalyst, with corresponding absorption bands lying in the visible spectral range. The photoexcitation of such impurities should lead to the generation of free charge carriers to initiate surface chemical processes but the efficiency of such systems under visible light strongly depended on the preparation method used. In some cases, such doped photocatalyst showed no activity under visible light and lower activity in the UV spectral range compared with the non-doped photocatalyst because of high carrier recombination rates through the metal ion levels [26].

In this present work, we report the structural, optical, morphological, IR and photo catalytic properties of pure and $\mathrm{Cu}$ doped nanoparticles. A number of samples of $\mathrm{Cu}$ doped $\mathrm{ZnO}$ with different concentrations were synthesized by using co-precipitation method. The photo catalytic studies of prepared samples were evaluated by recording the spectra of methylene blue dye solution with catalyst at regular intervals.

\section{Materials and Experimental}

\subsection{Synthesis of Doped and Undoped Zno}

All chemicals used to prepare pure and $\mathrm{Cu}$ doped $\mathrm{ZnO}$ were purchased from Sigma-Aldrich and used without further purification. The $\mathrm{Zn}_{1-\mathrm{x}} \mathrm{Cu}_{\mathrm{x}} \mathrm{O}$ nanopowder $(\mathrm{x}=0.0,0.01,0.02$ and 0.03$)$ were prepared by co-precipitation method using zinc acetate dihydrate as the source of zinc and copper acetate were used as the source of dopants. In typical process zinc acetate dihydrate and copper acetate in their respective stoichiometry were dissolved in ethanol separately. Both the solutions were mixed thoroughly and to this mixture $\mathrm{NaOH}$ solution in ethanol were added by constant magnetic stirring for 2 hours at room temperature. The obtained precipitate was separated from the solution by filtration, washed several times with distilled water and ethanol then dried in air at $100^{\circ} \mathrm{C}$ and calcined at $450^{\circ} \mathrm{C}$ for 8 hours to obtain $\mathrm{Cu}$ doped $\mathrm{ZnO}$ nanocrystals ( $\mathrm{x}=0.01,0.02$ and 0.03 ). Undoped $\mathrm{ZnO}$ $(\mathrm{x}=0.0)$ was synthesized by the similar process except with copper acetate.

\subsection{Photocatalytic Activity}

The photocatalytic degradation of methylene blue was determined by using $25 \mathrm{ml}$ aqueous solution (with initial concentration $20 \mathrm{ppm}$ ) and $20 \mathrm{mg}$ of catalyst in a $100 \mathrm{ml}$ quartz beaker. The solution was stirred in dark for 15 minute to allow the equilibrium to take place between methylene blue dye solution and the catalyst. The photo- 
degradations were carried out using five UV tubes (6 W each of wavelength $365 \mathrm{~nm}$ ) keeping the sample at horizontal position at a distance $15 \mathrm{~cm}$ in a batch reactor. At different time intervals $5 \mathrm{ml}$ sample was collected and centrifuged to separate the catalyst from the solution to record the spectra on Shimadzu UV-visible Spectrophotometer (UV-1800). After recording spectra the sample was pour back to original dye solution. All the experiments were carried out at identical condition and at room temperature. The degradation of methylene blue dye solution was noticed by integrating area under the absorbance curve. The percentage degradation (removal) was calculated by using following equation;

$$
\% \text { removal }=\left[\frac{C_{0}-C_{t}}{C_{0}}\right] \times 100
$$

where $C_{0}$ and $C_{t}$ are the concentration of the methylene blue dye solution at the initial and any other time, respectively.

\section{Result and Discussion}

\subsection{XRD Analysis}

The crystal structure of $\mathrm{Zn}_{1-\mathrm{x}} \mathrm{Cu}_{\mathrm{x}} \mathrm{O}$ samples with concentration $\mathrm{x}=0.0,0.01,0.02$ and 0.03 shown in Figure 1 were determined by X-ray diffractometer (Bruker D8 Advance Diffractometer) with CuK $\alpha$ radiations ( $\lambda=$ $1.5416 \AA$ ) in the range of $20^{\circ}$ to $80^{\circ}$ at room temperature. The sharp intense peak obtained in all the samples at $2 \theta \approx 30.80,34.22,35.38,46.70,54.88,62.02,67.12$ and 68.23 corresponds to the lattice plane (100), (002), (101), (102), (110), (103), (112) and (201) respectively confirms that the prepared samples are good crystalline in nature with wurtzite hexagonal structure and are agree with the JCPDS data (01-075-1533).

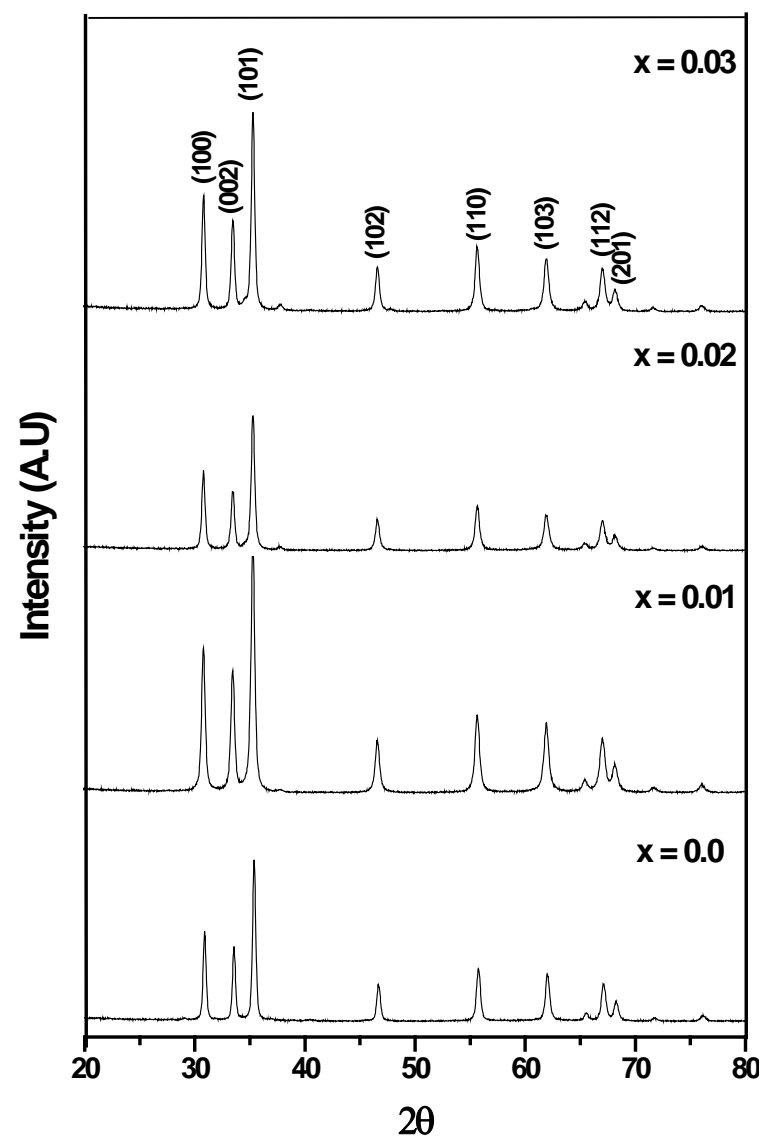

Figure 1. XRD pattern of $\mathrm{Zn}_{1-\mathrm{x}} \mathrm{Cu}_{\mathrm{x}} \mathrm{O}$ samples with concentration $\mathrm{x}=0.0,0.01,0.02$ and 0.03 . 
The structural data obtained from XRD pattern of pure and $\mathrm{Cu}$ doped $\mathrm{ZnO}$ nanomaterial is tabulated in the Table 1. The plot of lattice parameters "a" and "c" versus Cu concentration is shown in Figure 2. From Figure 2 , it is observed that the lattice parameter "c" increase rapidly upto $1 \%$, then slowly increase upto $2 \%$ and then decreases rapidly. At the same time the lattice parameter "a" decrease rapidly upto $1 \%$, then slowly decrease upto $2 \%$ and then increase rapidly. This may be discussed in details as; the $\mathrm{Cu}$ can exist in $\mathrm{Cu}^{+}, \mathrm{Cu}^{2+}$ and $\mathrm{Cu}^{3+}$ ions having ionic radii $0.77 \AA, 0.73 \AA \& 0.54 \AA$ respectively. This shows that the lattice parameter "c" increase rapidly upto $1 \%$ due to the substitution of $\mathrm{Cu}^{+}$ions into the $\mathrm{Zn}^{2+}$ ions since the ionic radius of $\mathrm{Cu}^{2+}(0.73 \AA)$ is greater than of $\mathrm{Zn}^{2+}(0.74 \AA)$. The slow increment in lattice parameter "c" from concentration $1 \%$ to $2 \%$ shows that the substitution of $\mathrm{Cu}^{+}(0.77 \AA)$ and $\mathrm{Cu}^{2+}(0.73 \mathrm{~A} \AA)$ ions in $\mathrm{Zn}^{2+}(0.74 \AA)$ site indicating that the percentage of $\mathrm{Cu}^{+}(0.77 \AA)$ ions is slightly more than $\mathrm{Cu}^{2+}(0.73 \AA)$ ions. This means there is a transition phase of $\mathrm{Cu}^{+}$and $\mathrm{Cu}^{2+}$ ions from $1 \%$ to $2 \%$ of $\mathrm{Cu}$ dopant. The lattice parameter "c" decreases rapidly after $2 \%$ of $\mathrm{Cu}$, owing to substitution of $\mathrm{Cu}^{2+}(0.73 \AA)$ and $\mathrm{Cu}^{3+}(0.54 \AA)$ ions in $\mathrm{Zn}$ site.

The number of unit cell in particle is calculated by using formula [27],

$$
N=\frac{4}{3 \pi \frac{D}{2 V}}
$$

It is observed that the number of unit cell per particle increases upto $2 \%$ and then decreases. This shows that the ionic radii of $\mathrm{Cu}$ ions leads to shrinking of unit cell per particle in such way that lattice parameter "c" increase as "a" decrease and vice versa.

Table 1. Lattice parameter, volume of unit cell, $\mathrm{x}$-ray density, atomic packing fraction, c/a ratio, grain size, $\mathrm{W}-\mathrm{H}$ grain size and strain of $\mathrm{Zn}_{1-\mathrm{x}} \mathrm{Cu}_{\mathrm{x}} \mathrm{O}$ samples with concentration $\mathrm{x}=0.0,0.01,0.02$ and 0.03 .

\begin{tabular}{|c|c|c|c|c|c|c|c|c|c|c|}
\hline \multirow{2}{*}{$\begin{array}{c}\text { Conc. } \\
(\mathrm{x})\end{array}$} & \multicolumn{2}{|c|}{$\begin{array}{c}\text { Lattice parameter } \\
\text { in }(\AA)\end{array}$} & \multirow{2}{*}{$\begin{array}{l}\text { Volume } \\
\text { in }(\AA)^{3}\end{array}$} & \multirow{2}{*}{$\begin{array}{c}\text { X-ray } \\
\text { density } D_{x} \\
\text { in }\left(\mathbf{k g} / \mathrm{cm}^{3}\right)\end{array}$} & \multirow{2}{*}{$\begin{array}{l}\text { Atomic } \\
\text { packing } \\
\text { factor }\end{array}$} & \multirow[t]{2}{*}{ c/a ratio } & \multirow{2}{*}{$\begin{array}{c}\text { Grain } \\
\text { size (D) } \\
\text { in } \mathrm{nm}\end{array}$} & \multirow{2}{*}{$\begin{array}{c}\text { W-H grain } \\
\text { size }(\mathrm{G}) \\
\text { in } \mathbf{~ n m}\end{array}$} & \multirow{2}{*}{$\begin{array}{l}\text { Strain } \\
(\varepsilon)\end{array}$} & \multirow{2}{*}{$\begin{array}{c}\text { Energy } \\
\text { Band } \\
\text { Gap }(e V)\end{array}$} \\
\hline & $\mathrm{a}$ & c & & & & & & & & \\
\hline 0.00 & 3.3287 & 5.2777 & 50.6421 & 5.3399 & 0.7273 & 1.5855 & 28.69 & 39.49 & 0.00102 & 3.46 \\
\hline 0.01 & 3.3113 & 5.3465 & 50.7674 & 5.3267 & 0.7142 & 1.6146 & 23.94 & 33.16 & 0.00121 & 3.27 \\
\hline 0.02 & 3.3109 & 5.3475 & 50.7646 & 5.3270 & 0.7140 & 1.6151 & 25.83 & 40.41 & 0.00148 & 3.20 \\
\hline 0.03 & 3.3197 & 5.2864 & 50.4517 & 5.3601 & 0.7242 & 1.5924 & 26.67 & 40.17 & 0.00134 & 3.55 \\
\hline
\end{tabular}

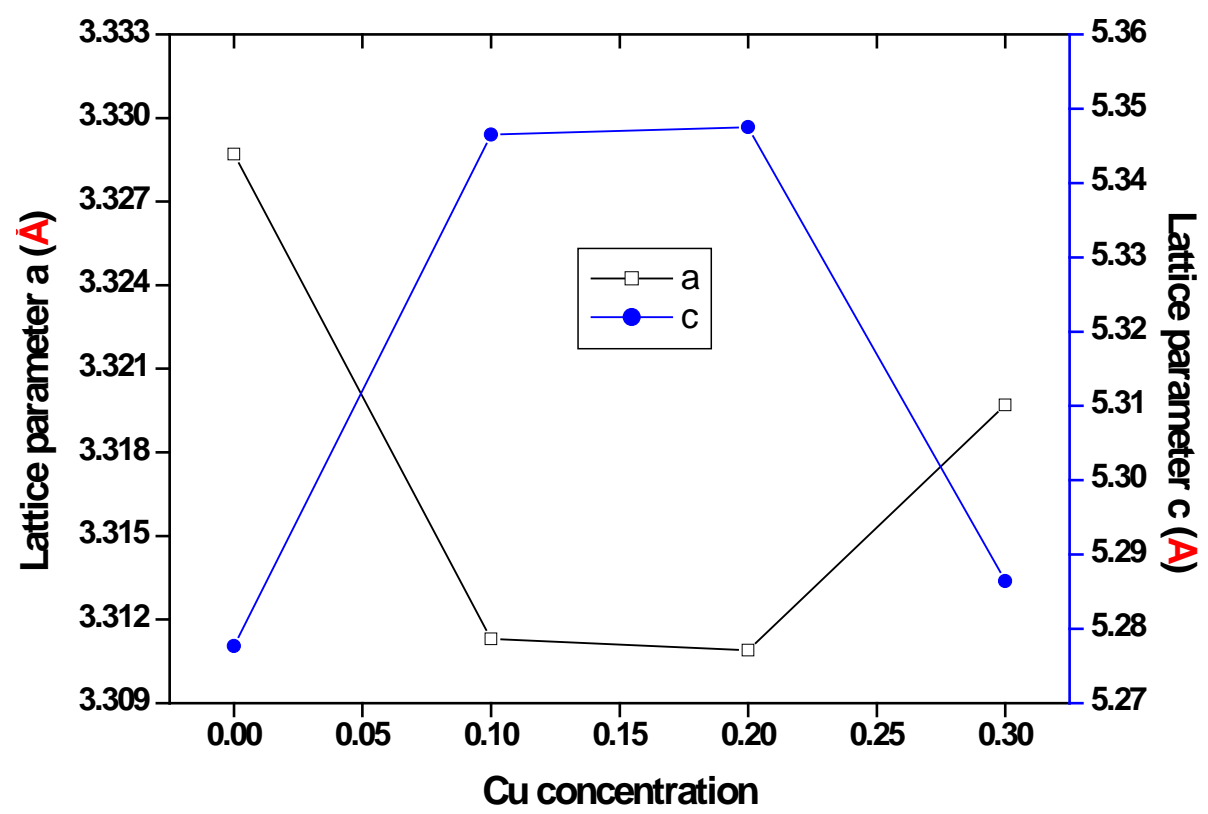

Figure 2. Lattice parameters “a” and "c" versus $\mathrm{Cu}$ concentration. 
The volume of unit cell can be determined by using well known formula,

$$
V=0.866 \mathrm{a}^{2} \mathrm{c} .
$$

The volume of unit cell versus $\mathrm{Cu}$ concentration is shown in Figure 3. It is observed that the volume of unit cell increases rapidly upto $1 \%$ of dopant concentration and then slightly decrease up to $2 \%$ and then suddenly decreases. This may lead due to the defect or vacancies formation in the transition phase of $\mathrm{Cu}^{+}, \mathrm{Cu}^{2+}$ and $\mathrm{Cu}^{3+}$ ions during sintering or diffusion process.

The X-ray density of ZnO sample was calculated by using the formula [28],

$$
D_{x}=\frac{n M}{N_{A} V}
$$

where, $D_{x}$ is X-ray density, $n$ is the number of atoms per unit cell, $M$ is the molecular weight of the sample, $N_{A}$ is Avagadro's number and $V$ is the volume of unit cell. It is observed that the $\mathrm{X}$-ray density depend on molecular weight of the sample as well as volume of the unit cell.

It is observed from the Table 1 that the average atomic packing fraction (APF) of all samples is $\approx 0.73$ which is in good agreement with the standard wurtzite hexagonal structure. The c/a ratio shows that the isotropic nature of the prepared materials.

A definite line broadening of the diffraction peak (101) of pure and $\mathrm{Cu}$ doped $\mathrm{ZnO}$ samples is an indication that the synthesized materials are in nanometer range. The crystallite size $(D)$ was calculated from line broadening of the major XRD peak (101) using the Scherrer's formula [29].

$$
D=\frac{K \lambda}{\beta \cos \theta}
$$

where, $K$ is the shape factor, which is a constant taken as $0.9, \lambda$ is the wavelength of the $\mathrm{X}$-ray radiation ( $\lambda=$ $1.5416 \AA$ ), $\beta$ is the full-width at half-maximum (FWHM) in radians, $\theta$ is the Bragg's angle in degree. The crystallite size of the pure and $\mathrm{Cu}$ doped $\mathrm{ZnO}$ sample obtained from Equation (4) are listed in Table 1. It is found that the samples synthesized by co precipitation route have grain size between 23 - $29 \mathrm{~nm}$.

In order to understand the peak broadening with lattice strains, various peaks appeared in the XRD pattern were used. The Stokes and Wilson [30] formula given in Equation (5) were used to calculate the strain induced broadening of the Bragg's diffraction peak.

$$
\varepsilon=\frac{\beta_{h k l}}{4 \tan \theta}
$$

The W-H plot of $\beta_{h k l} \cos \theta$ versus $4 \sin \theta$ for $\mathrm{Zn}_{1-\mathrm{x}} \mathrm{Cu}_{\mathrm{x}} \mathrm{O}$ samples with concentration $\mathrm{x}=0.0,0.01,0.02$

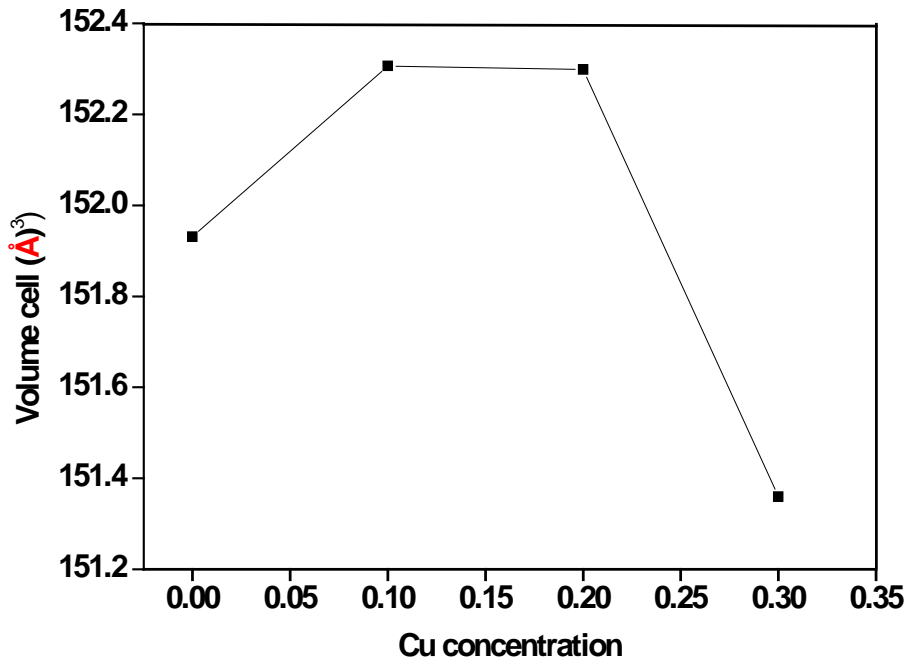

Figure 3. Volume of unit cell versus Cu concentration. 
and 0.03 are shown in Figures 4(a)-(d). It is well known that, in the absence of strain in broadening of peak, the $\beta_{h k l} \cos \theta$ versus $4 \sin \theta$ plot is expected to be a horizontal line parallel to the $4 \sin \theta$ axis and in the presence of strain in broadening of peak, it should have a non-zero slope. The obtained values of grain size and strain induced in the broadening of the peak are tabulated in Table 1. It is observed that the strain value increases up to doping 0.02 and then decreases. This may be due to the increment in number of unit cell per particle as a result of substitution of $\mathrm{Cu}^{+}, \mathrm{Cu}^{2+}$ and $\mathrm{Cu}^{3+}$ ions in $\mathrm{Zn}$ site.

\subsection{Optical Analysis}

The UV-vis spectra of pure and $\mathrm{Cu}$ doped $\mathrm{ZnO}$ samples recorded in the wavelength range $300-1100 \mathrm{~nm}$ at room temperature. The band gap was calculated by plotting the absorption plot $(\alpha \mathrm{h} v)^{2}$ versus (Energy, $E$ ) shown in Figure 5. The values of energy band gap calculated from Figure 5 are tabulated in Table 1 and it is found that the band gaps of pure and $\mathrm{Cu}$ doped $\mathrm{ZnO}$ samples are in the range $3.20-3.55 \mathrm{eV}$. It is observed that band gap decrease with increasing $\mathrm{Cu}$ concentration upto 0.2 and then increases. This may be due to decrease in strain as a result of increment in number of unit cell per particles.

\subsection{FTIR Analysis}

FTIR spectra (absorption vs wave number) of pure and $\mathrm{Cu}$ doped $\mathrm{ZnO}$ nanoparticles are shown in the Figure 6. The broad peak in higher energy region at $3740-3000 \mathrm{~cm}^{-1}$ is due to O-H stretching and peak in the lower range at $1524-1691 \mathrm{~cm}^{-1}$ is due to O-H bending. All other peaks are attributed to the characteristic of the prepared

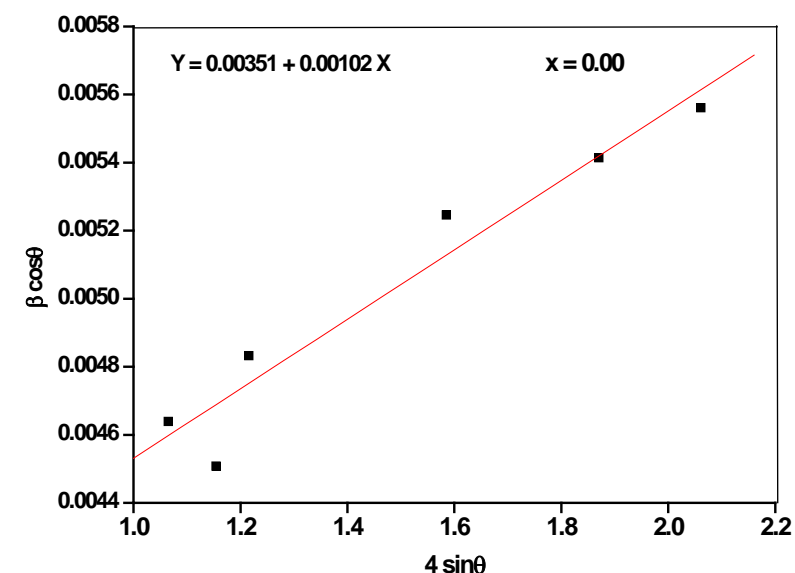

(a)

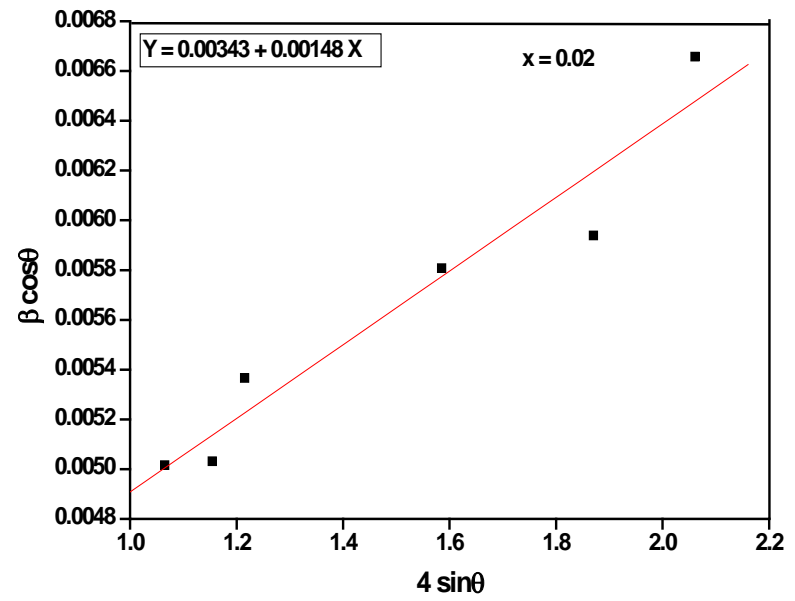

(c)

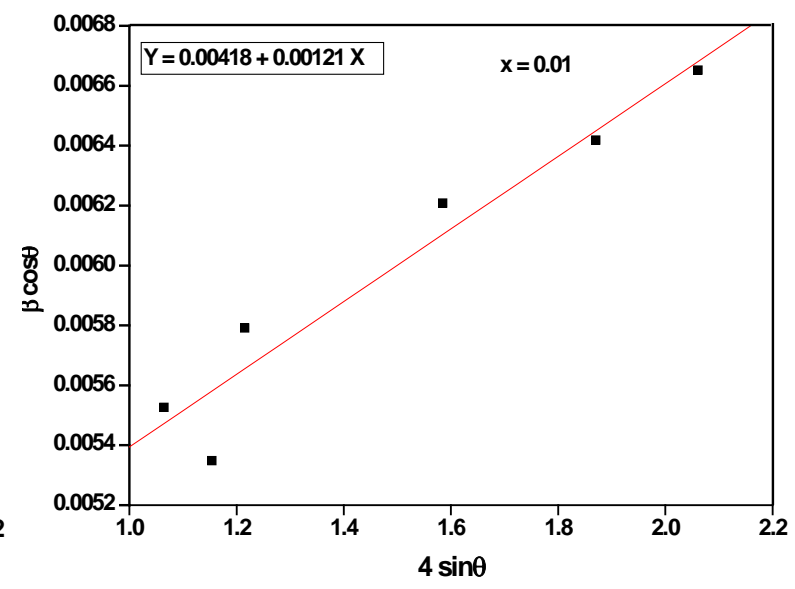

(b)

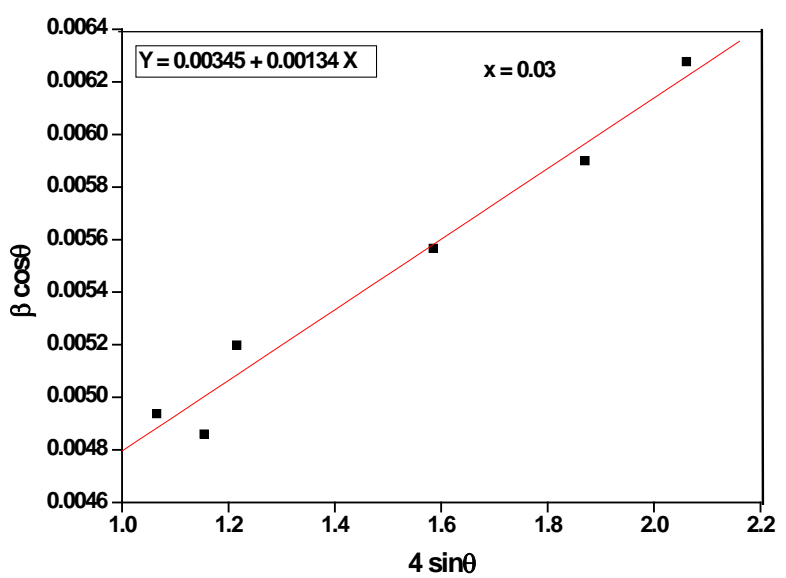

(d)

Figure 4. The $\mathrm{W}-\mathrm{H}$ plot of $\beta_{h k l} \cos \theta$ versus $4 \sin \theta$ for $\mathrm{Zn}_{1-\mathrm{x}} \mathrm{Cu}_{\mathrm{x}} \mathrm{O}$ samples. 


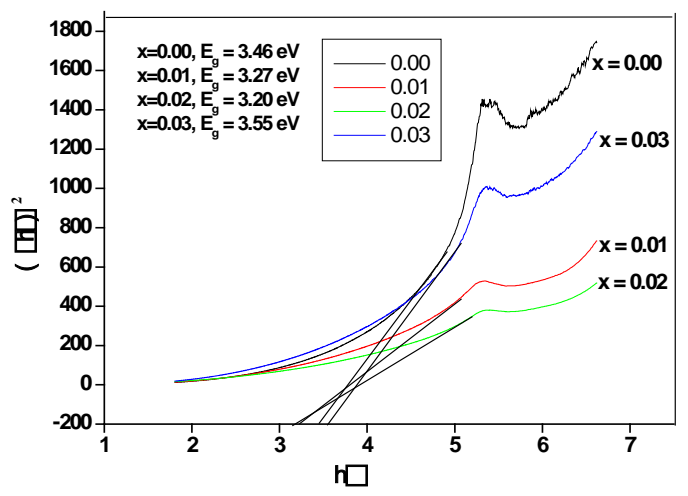

Figure 5. $(\alpha \mathrm{hv})^{2}$ versus energy of pure and $\mathrm{Cu}$ doped $\mathrm{ZnO}$.

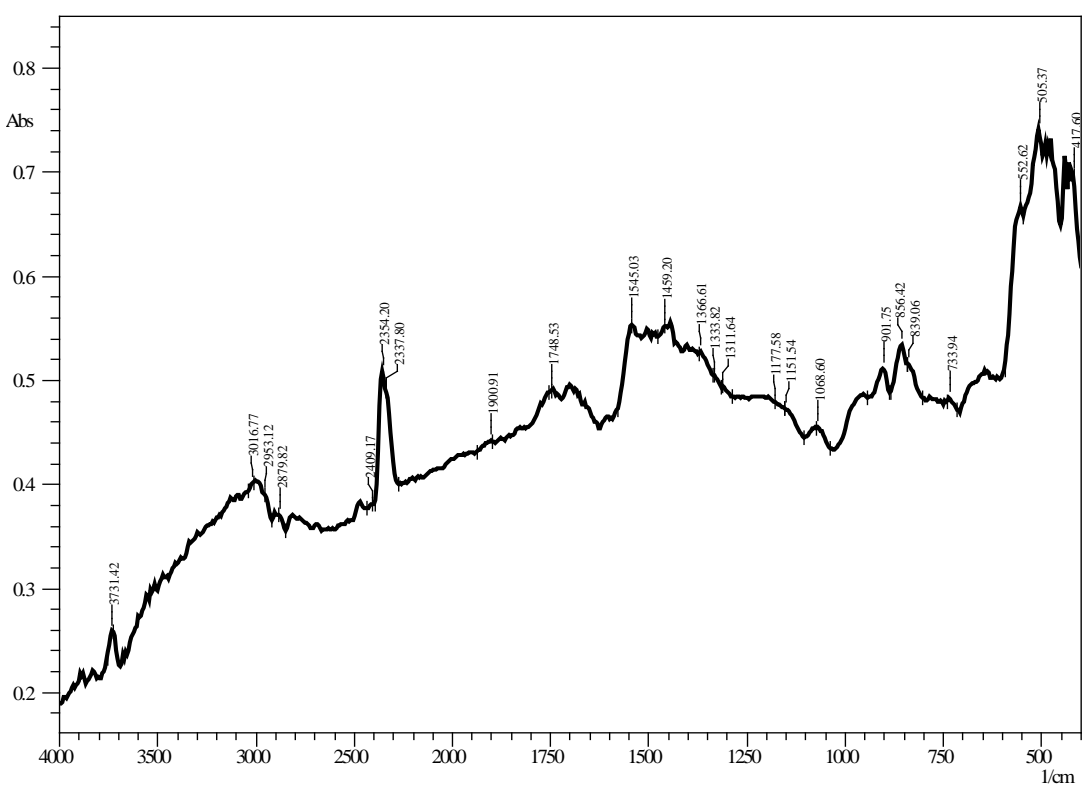

(a)

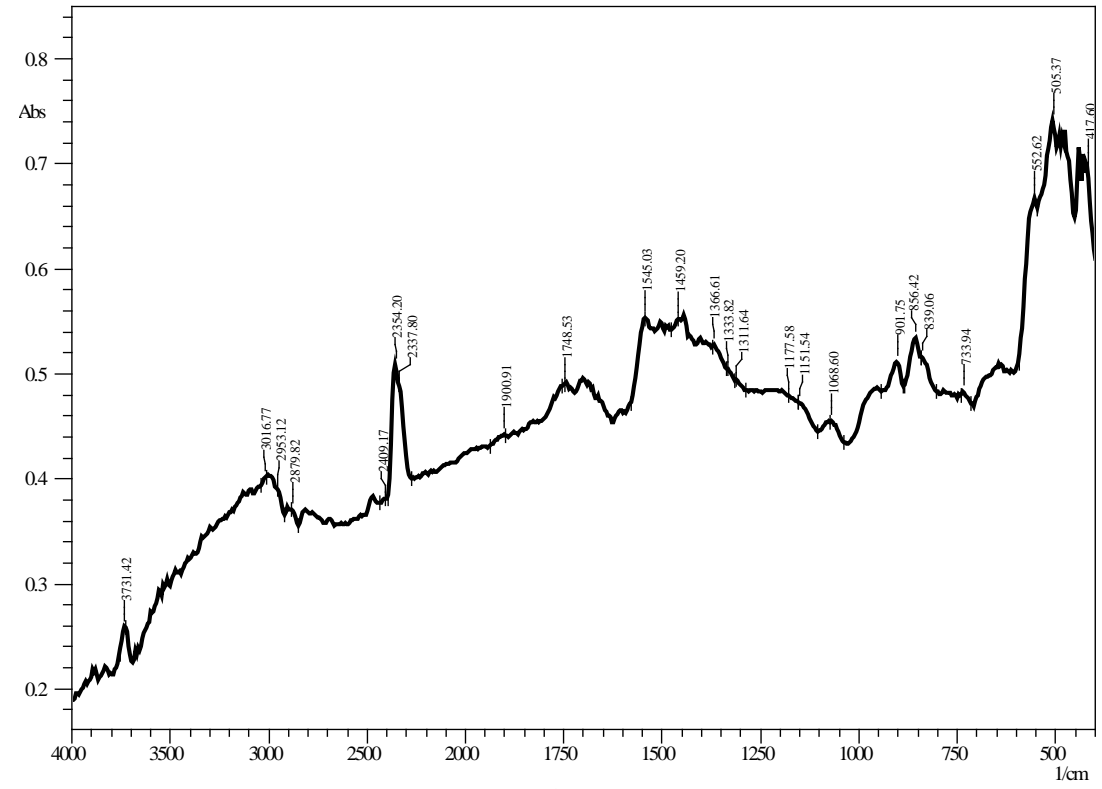

(b) 


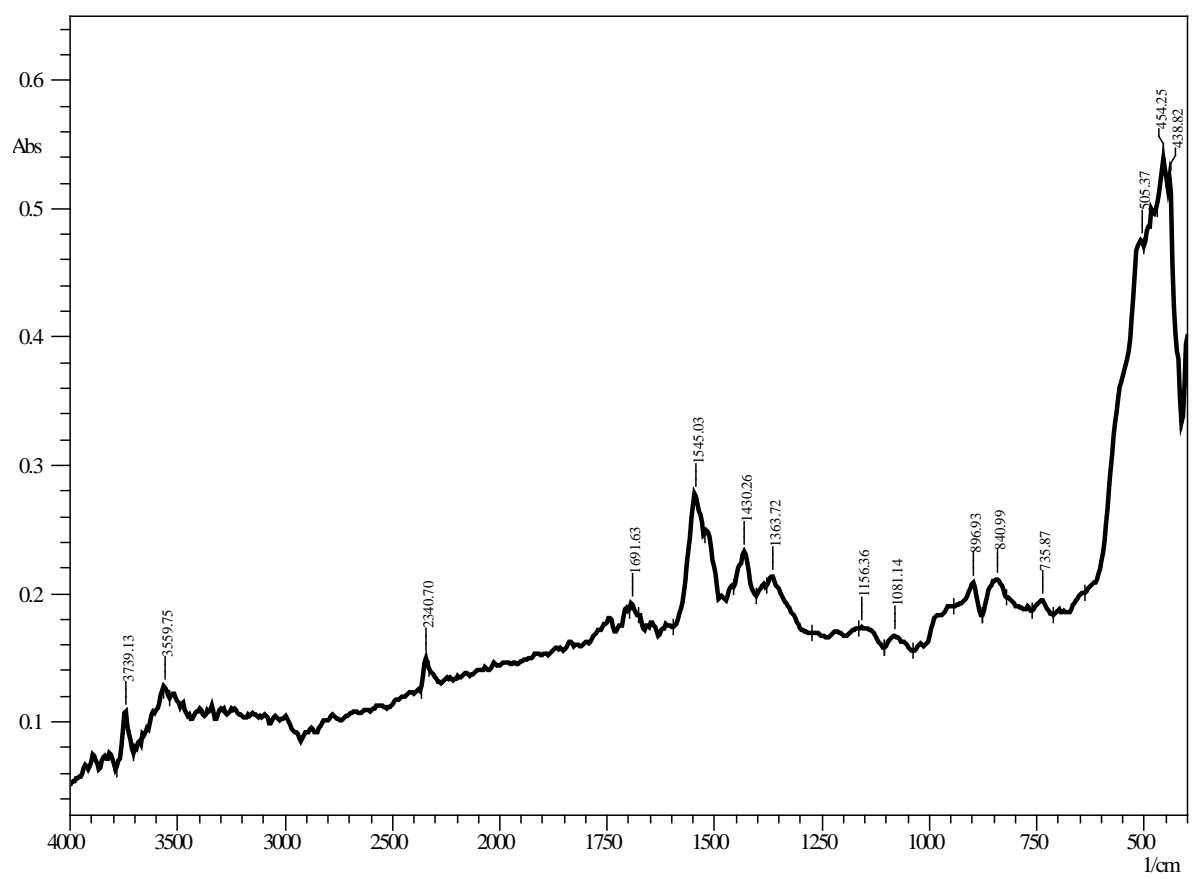

(c)

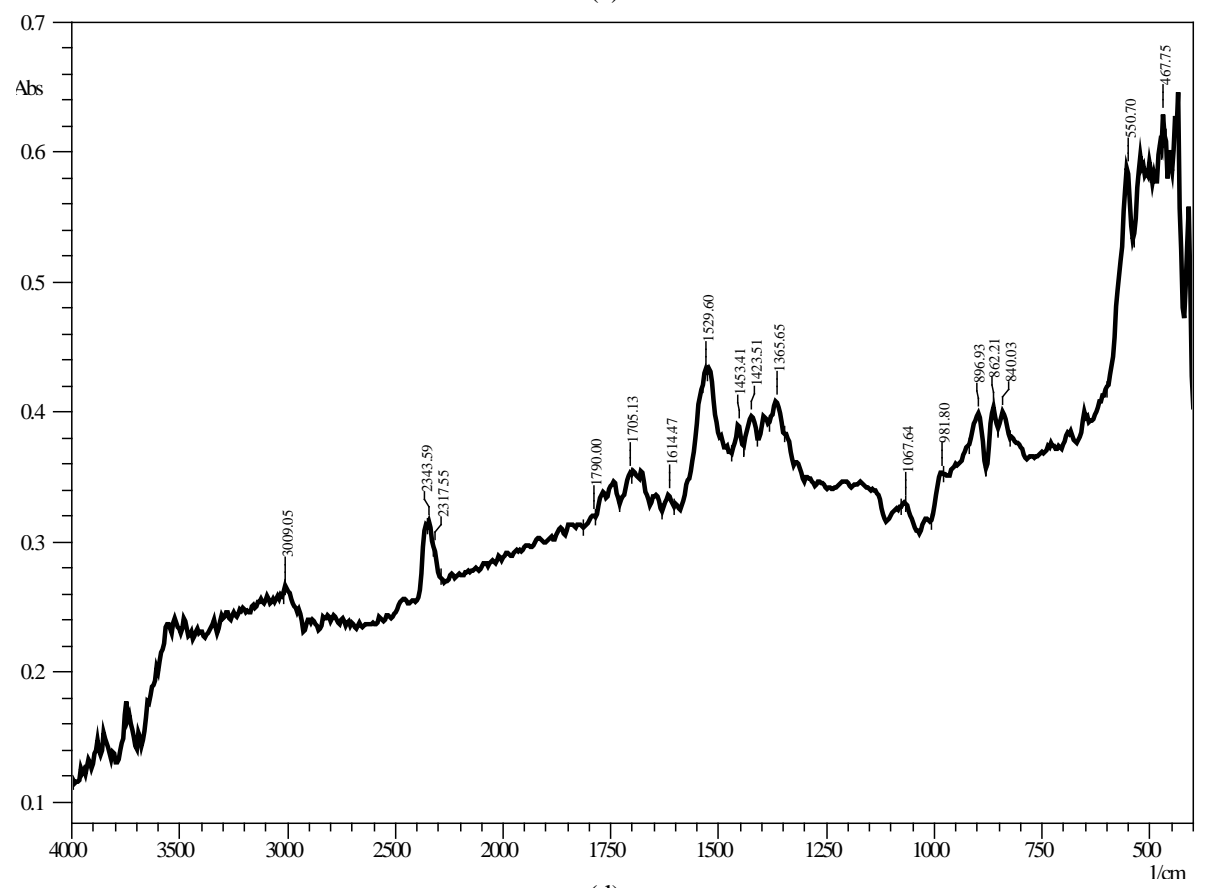

(d)

Figure 6. FTIR spectra of $\mathrm{Zn}_{1-x} \mathrm{Cu}_{\mathrm{x}} \mathrm{O}$ (a) $\mathrm{x}=0.00$, (b) $\mathrm{x}=0.01$, (c) $\mathrm{x}=0.02$ and (d) $\mathrm{x}=0.03$.

pure and $\mathrm{Cu}$ doped $\mathrm{ZnO}$ nanoparticles. The bands appeared near at $1900-2354 \mathrm{~cm}^{-1}$ indicates the $\mathrm{CO}$ adsorption on the surface of oxide. Similarly the bands at $780-980 \mathrm{~cm}^{-1}$ might be due to the peroxide formation (M-O-O-M). The FTIR spectrum of the main absorption band is due to $\mathrm{Zn}-\mathrm{O}$ stretching of $\mathrm{ZnO}$ in the range of $552-417 \mathrm{~cm}^{-1}$.

\subsection{Photocatalytic Analysis}

No measurable dye degradation was observed without catalyst under UV light (without catalyst) and in dark 
(with catalyst). The potential of $\mathrm{ZnO}$ nanoparticles towards degradation of dye solution was tested by adding different mass of $\mathrm{ZnO}(5,10,20,50$ and $100 \mathrm{mg})$ in $20 \mathrm{ppm} 25 \mathrm{ml}$ methylene blue solution at $\mathrm{pH}=6$ under atmospheric pressure and at room temperature. Figure 7 illustrates the effect of catalyst concentration towards the degradation of methylene blue solution. The degradation of methylene blue increases as the mass of $\mathrm{ZnO}$ increases from 5 to $100 \mathrm{mg}$ but after $20 \mathrm{mg}$ of $\mathrm{ZnO}$, photocatalytic degradation does not improved significantly. All further catalytic photocatalytic activities were restricted to $20 \mathrm{mg}$ (optimum concentration for $25 \mathrm{ml}$ methylene blue solution). Optimum concentration of the catalyst depends on the experimental setup (working condition) and the incident radiation. Figure 8 shows the absorption spectra of methylene blue solution with pure and $\mathrm{Cu}$ doped $\mathrm{ZnO}$ respectively, under UV light irradiation. By observing percentage removal curve (Figure 9), it is clear that undoped $\mathrm{ZnO}$ is more effective photocatalyst as compared to $\mathrm{Cu}$ doped $\mathrm{ZnO}$. The photocatalytic efficiency of $\mathrm{ZnO}$ nanoparticles decreases with increasing $\mathrm{Cu}$ concentration. This is in accordance with $\mathrm{C}$. M. Teh and A. R. Mohamed [31], the doped metal oxide had thermal instability and the metal ions doped into metal oxide have been verified as the main cause for the partial blockage of surface sites available for photocatalytic activity [32].

\subsection{Reaction Mechanism}

In the photocatalytic oxidation process the reactive species $\operatorname{are~}^{+},{ }^{\cdot} \mathrm{OH}$, and ${ }^{\circ} \mathrm{O}_{2}$. In order to find out the main

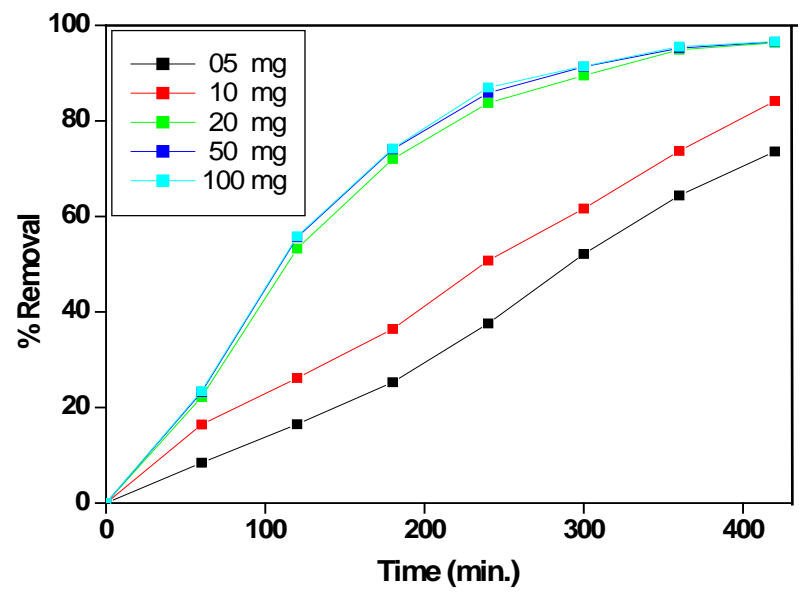

Figure 7. Percentage removal at different concentration of pure $\mathrm{ZnO}(\mathrm{x}=0.0)$.

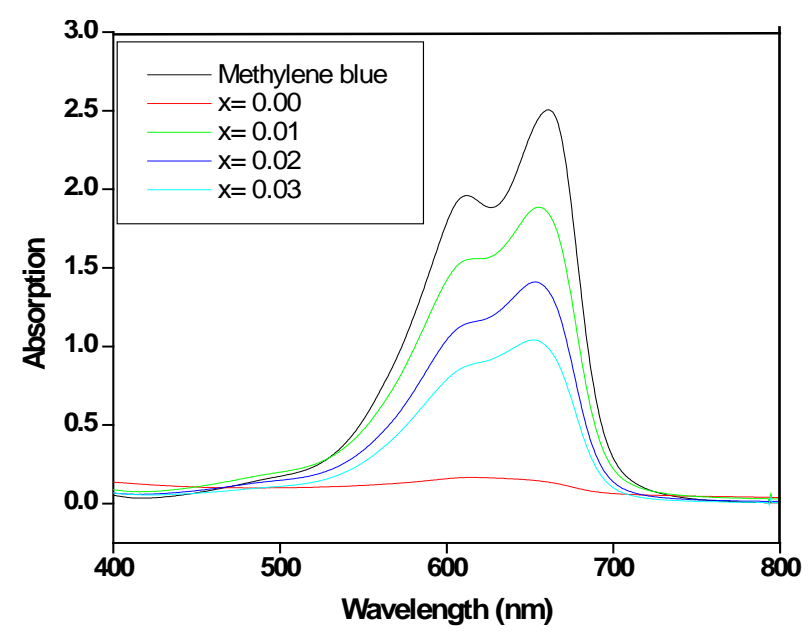

Figure 8. Absorbance change in methylene blue solution at $662 \mathrm{~nm}$ with doped $\mathrm{ZnO}(20 \mathrm{mg})$ at different concentration of $\mathrm{Cu}$ after 360 minute. 
reactive species resposible for the degradation of dyes, the scavenger study was performed. In this study ammonium oxalate, benzoquinone and isopropanol were used to remove $\mathrm{h}^{+}, \cdot \mathrm{OH}$, and ${ }^{\cdot} \mathrm{O}_{2}$ respectively [33]. By adding ammonium oxalate, methylene blue solution undergoes degradationin regular manner, while the addition of isopropanol and benzoquinone does not produce any kind of degradation. These results indiacate that ${ }^{\circ} \mathrm{OH}$ and ${ }^{\circ} \mathrm{O}_{2}$ are the main reactive species for all samples in the photocatalytic degradation process.

\subsection{Morphological Analysis}

The scanning electron microscopy (SEM) images of pure and $\mathrm{Cu}$ doped $\mathrm{ZnO}$ is shown in Figure 10. The SEM

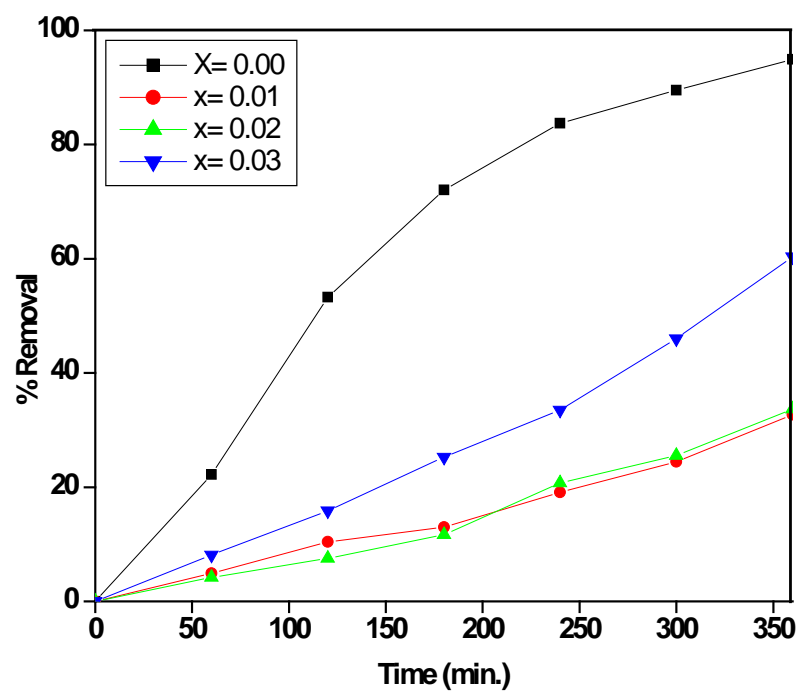

Figure 9. Percentage removal curve of methylene blue solution with doped $\mathrm{ZnO}(20 \mathrm{mg})$ at different concentration of $\mathrm{Cu}$.
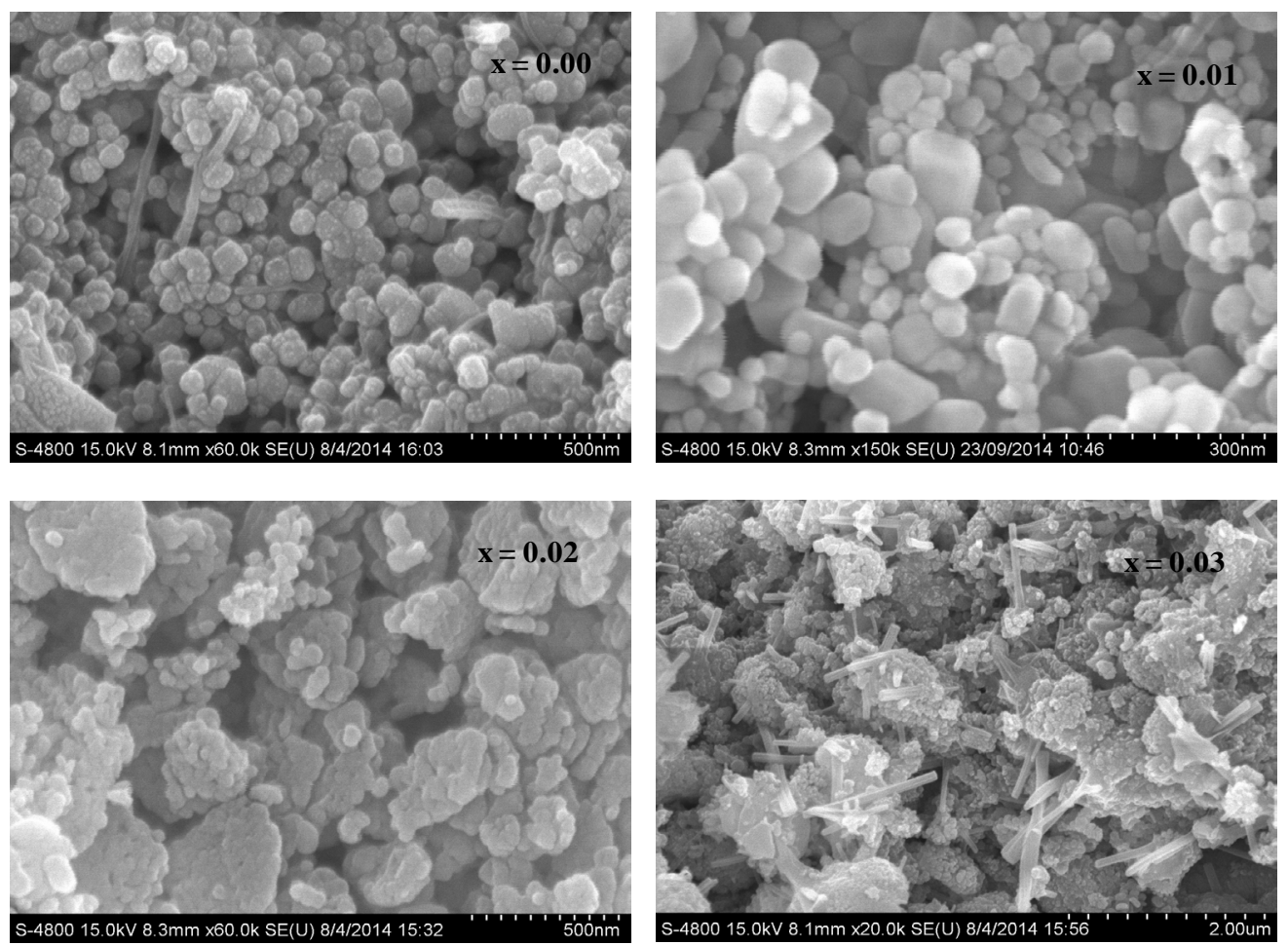

Figure 10. SEM images of $\mathrm{Zn}_{1-\mathrm{x}} \mathrm{Cu}_{\mathrm{x}} \mathrm{O}$ samples. 
micrograph indicates that the shape and morphology of $\mathrm{ZnO}$ nanoparticles changes with increasing Cu concentration. These images revealed that the individual particles were composed by the collection of particles of various shapes with increasing $\mathrm{Cu}$ concentration. This indicates that doping of $\mathrm{Cu}$ ions influences strongly on morphology of $\mathrm{ZnO}$ nanoparticles. These images also show that the agglomeration in nanoparticles increases with increasing $\mathrm{Cu}$ concentration and dispersivity, homogeneity of particles was not good. This may be owing to the calcinations temperature which was $450^{\circ} \mathrm{C}$ and substitution of different $\mathrm{Cu}^{+}, \mathrm{Cu}^{2+}$ and $\mathrm{Cu}^{3+}$ ion in $\mathrm{Zn}$ site with increasing $\mathrm{Cu}$ concentration.

\section{Conclusion}

In summary, Pure and $\mathrm{Cu}(1 \%, 2 \%$ and $3 \%$ at wt) doped $\mathrm{ZnO}$ samples successively prepared by co-precipitation method at room temperature. From XRD data it is confirmed that all the samples are good crystalline in nature with wurtzite hexagonal structure. The lattice parameters "a" and "c" indicate that $\mathrm{Cu}^{+}, \mathrm{Cu}^{2+}$ and $\mathrm{Cu}^{3+}$ ions substitute in $\mathrm{Zn}$ site with increasing $\mathrm{Cu}$ concentration. The change in volume of unit cell may be due to the defects or vacancy formation in the transition phase of $\mathrm{Cu}^{+}, \mathrm{Cu}^{2+}$ and $\mathrm{Cu}^{3+}$ ions during diffusion process. The absorption spectra show that the value of energy band gap varies due to the influence of strain. The chemical groups of samples are identified by FTIR spectra and prominent IR peaks are analyzed. Photocatalytic measurements reveal that increase in $\mathrm{Cu}$ doping in $\mathrm{ZnO}$ nanoparticles does result in lower photocatalytic activity.

\section{Acknowledgements}

P. K. Labhane would like to thank University Grants Commission, New Delhi, for financial support through research project 47-815/13 (WRO) and UDCT, North Maharashtra University, Jalgaon for providing characterization facilities.

\section{References}

[1] Xia, S.S., Zha, L., Leng, X.N., Lang, X.Y. and Lian, J.S. (2014) Synthesis of Amorphous $\mathrm{TiO}_{2}$ Modified ZnO Nanorod Film with Enhanced Photocatalytic Properties. Applied Surface Science, 299, 97-104. http://dx.doi.org/10.1016/j.apsusc.2014.01.192

[2] Kundu, S. (2014) A Facile Route for the Formation of Shape Selective ZnO Nanoarchitectures with Superior Photocatalytic Activity. Colloids and Surfaces A: Physiochemical and Engineering Aspects, 446, 199-212.

[3] Huang, J., Yin, Z.G. and Zheng, Q.D. (2011) Applications of ZnO in Organic and Hybrid Solar Cells. Energy \& Environmental Science, 4, 3861-3877. http://dx.doi.org/10.1039/c1ee01873f

[4] Xu, F. and Sun, L.T. (2011) Solution-Derived ZnO Nanostructures for Photoanodes of Dye-Sensitized Solar Cells. Energy \& Environmental Science, 4, 818-841. http://dx.doi.org/10.1039/C0EE00448K

[5] Wang, P.-P., Qi, Q., Xuan, R.-F., Zha, J., Zhou, L.-J. and Li, G.-D. (2013) A Facile Method for Enhancing the Sensing Performance of Zinc Oxide Nanofibers Gas Sensors. RSC Advances, 3, 19853-19856. http://dx.doi.org/10.1039/c3ra43301c

[6] Alenezi, M.R., Henley, S.J., Emerson, N.G. and Silva, S.R.P. (2014) From 1D and 2D Nanostructures to 3D Hierarchical Structures with Enhanced Gas Sensing Properties. Nanoscale, 6, 235-247. http://dx.doi.org/10.1039/C3NR04519F

[7] Qin, Y., Wang, X.D. and Wang, Z.L. (2008) Microfiber-Nanowire Hybrid Structure for Energy Scavenging. Nature, 451, 809-813. http://dx.doi.org/10.1038/nature06601

[8] Song, H.S., Zhang, W.J., Cheng, C., Tang, Y.B., Luo, L.B., Chen, X., Luan, C.Y., Meng, X.M., Zapien, J.A., Wang, N., Lee, C.S., Bello, I. and Lee, S.T. (2011) Controllable Fabrication of Three-Dimensional Radial ZnO Nanowire/Silicon Microrod Hybrid Architectures. Crystal Growth \& Design, 11, 147-153. http://dx.doi.org/10.1021/cg101062e

[9] Xie, Y.P., He, Y.P., Irwin, P.L., Jin, T. and Shi, X.M. (2011) Antibacterial Activity and Mechanism of Action of Zinc Oxide Nanoparticles against Campylobacter jejuni. Applied and Environmental Microbiology, 77, 2325-2331. http://dx.doi.org/10.1128/AEM.02149-10

[10] Fageria, P., Gangopadhyay, S. and Pande, S. (2014) Synthesis of ZnO/Au and ZnO/Ag Nanoparticles and Their Photocatalytic Application Using UV and Visible Light. RSC Advances, 4, 24962-24972. http://dx.doi.org/10.1039/c4ra03158j

[11] Wu, D.W., Huang, Z.B., Yin, G.G., Ya, Y.D., Lia, X.M., Han, D., Huang, X. and Gu, J.W. (2012) Preparation, Structure and Properties of Mn-Doped ZnO Rod Arrays. CrystEngComm, 12, 192-198. http://dx.doi.org/10.1039/B909780E 
[12] Kaur, J., Kotnala, R.K., Gupta, V. and Verma, K.C. (2014) Anionic Polymerization in Co and Fe Doped ZnO: Nanorods, Magnetism and Photoactivity. Current Applied Physics, 14, 749-756. http://dx.doi.org/10.1016/j.cap.2014.03.002

[13] Kuriakose, S., Satpatib, B. and Mohapatra, S. (2014) Enhanced Photocatalytic Activity of Co Doped ZnO Nanodisks and Nanorods Prepared by a Facile Wet Chemical Method. Physical Chemistry Chemical Physics, 16, 12741-12749. http://dx.doi.org/10.1039/c4cp01315h

[14] Li, L., Wang, W., Liu, H., Liu, X., Song, Q. and Ren, S. (2009) First Principles Calculations of Electronic Band Structure and Optical Properties of Cr-Doped ZnO. The Journal of Physical Chemistry C, 113, 8460-8464. http://dx.doi.org/10.1021/jp811507r

[15] Ahmad, M., Ahmed, E., Zhang, Y.W., Khalid, N.R., Xu, J.F., Ullah, M. and Hong, Z.L. (2013) Preparation of Highly Efficient Al-Doped ZnO Photocatalyst by Combustion Synthesis. Current Applied Physics, 13, 4697-704. http://dx.doi.org/10.1016/j.cap.2012.11.008

[16] Zhong, J.B., Li, J.Z., He, X.Y., Zeng, J., Lu, Y., Hu, W. and Lin, K. (2012) Improved Photocatalytic Performance of Pd-Doped ZnO. Current Applied Physics, 12, 998-1001.

[17] Ca, F.-F., Xin, S., Guo, Y.-G. and Wan, L.-J. (2011) Wet Chemical Synthesis of $\mathrm{Cu} / \mathrm{TiO}_{2}$ Nanocomposites with Integrated Nano-Current Collectors as High Rate Anode Materials in Lithium-Ion Batteries. Physical Chemistry Chemical Physics, 13, 2014-2020. http://dx.doi.org/10.1039/c0cp01119c

[18] Karimi, M., Ezzati, M., Akbari, S. and Behtaj Lejbini, M. (2013) ZnO Microparticles, ZnO Nanoparticles and $\mathrm{Zn}_{0.9} \mathrm{Cu}_{0.1} \mathrm{O}$ Nanoparticles toward Ethanol Vapour Sensing: A Comparative Study. Current Applied Physics, 13, 17581764. http://dx.doi.org/10.1016/j.cap.2013.07.014

[19] Choudhary, B., Chawla, S., Jayanthi, K., Sood, K.N. and Singh, S. (2010) Synthesis and Surface Modification of ZnO:Cu Nanoparticles by Silica and PMMA. Current Applied Physics, 10, 3807-3812. http://dx.doi.org/10.1016/j.cap.2009.09.019

[20] Hegazy, A. and Prouzet, E. (2013) Effect of Physical Chemistry Parameters in Photocatalytic Properties of $\mathrm{TiO}_{2} \mathrm{Nano}^{-}$ crystals. Comptes Rendus Chimie, 16, 651-659. http://dx.doi.org/10.1016/j.crci.2013.04.008

[21] Guo, S.-Q., Zhang, X., Zhou, Z., Ga, G.-D. and Liu, L. (2014) Facile Preparation of Hierarchiral $\mathrm{Nb}_{2} \mathrm{O}_{5} \mathrm{Microspheres}$ with Photocatalytic Activities and Electrochemical Properties. Journal of Materials Chemistry A, 2, 9236-9243.

[22] Yu, Y., Zhang, L.Y., Wang, J., Yang, Z., Long M.C., Hu, N.T. and Zhang, Y.F. (2012) Preparation of Hollow Porous $\mathrm{Cu}_{2} \mathrm{O}$ Microspheres and Photocatalytic Activity under Visible Light Irradiation. Nanoscale Research Letters, 7, 347. http://dx.doi.org/10.1186/1556-276x-7-347

[23] Sreethawong, T., Ngamsinlapasathian, S. and Yoshikawa, S. (2013) Synthesis of Crystalline Mesoporous-Assembled $\mathrm{ZrO}_{2}$ Nanoparticles via a Facile Surfactant-Aided Sol-Gel Process and Their Photocatalytic Dye Degradation Activity. Chemical Engineering Journal, 228, 256-262. http://dx.doi.org/10.1016/j.cej.2013.04.111

[24] Kant, S. and Kumar, A. (2012) A Comparative Analysis of Structural, Optical and Photocatalytic Properties of ZnO and Ni Doped ZnO Nanospheres Prepared by Sol-Gel Method. Advanced Materials Letters, 3, 350-354. http://dx.doi.org/10.5185/amlett.2012.5344

[25] Zhong, J.B., Li, J.Z., He, X.Y., Zeng, J., Lu, Y., Hu, W. and Lin, K. (2012) Improved Photocatalytic Performance of Pd-Doped ZnO. Current Applied Physics, 12, 998-1001.

[26] Fujishima, A. and Zhang, X.T. (2006) Titanium Dioxide Photocatalysis: Present Situation and Future Approaches. Comptes Rendus Chimie, 9, 750-760. http://dx.doi.org/10.1016/j.crci.2005.02.055

[27] Menon, A.S., Kalarikkal, N. and Thomas, S. (2013) Studies on Structural and Optical Properties of ZnO and MnDoped ZnO Nanopowders. Indian Journal of NanoScience, 1, 16-24.

[28] Abdeen, A.M., Hemeda, O.M., Assem, E.E. and El-Sehly, M.M. (2002) Structural, Electrical and Transport Phenomena of Co Ferrite Substituted by Cd. Journal of Magnetism and Magnetic Materials, 238, 75-83. http://dx.doi.org/10.1016/S0304-8853(01)00465-6

[29] Tural, B., Betül Sopacı, Ş., Özkan, N., Demir, A.S. and Volkan, M. (2011) Preparation and Characterization of Surface Modified $\gamma-\mathrm{Fe}_{2} \mathrm{O}_{3}$ (Maghemite)-Silica Nanocomposites Used for the Purification of Benzaldehyde Lyase. Journal of Physics and Chemistry of Solids, 72, 968-973. http://dx.doi.org/10.1016/j.jpcs.2011.05.010

[30] Stokes, A.R. and Wilson, A.J.C. (1944) The Diffraction of X Rays by Distorted Crystal Aggregates-I, Proceedings of the Physical Society, 56, 174. http://dx.doi.org/10.1088/0959-5309/56/3/303

[31] The, C.M. and Mohamed, A.R. (2011) Roles of Titanium Dioxide and Ion-Doped Titanium Dioxide on Photocatalytic Degradation of Organic Pollutants (Phenolic Compounds and Dyes) in Aqueous Solutions: A Review. Journal of Alloys and Compounds, 509, 1648-1660. http://dx.doi.org/10.1016/j.jallcom.2010.10.181

[32] Rauf, M.A., Meetani, M.A. and Hisaindee, S. (2011) An Overview on the Photocatalytic Degradation of Azo Dyes in the Presence of $\mathrm{TiO}_{2}$ Doped with Selective Transition Metals. Desalination, 276, 13-27. 
http://dx.doi.org/10.1016/j.desal.2011.03.071

[33] Aboukais, A., Abi-Aad, E. and Tauk, B. (2012) Supported Manganese Oxide on $\mathrm{TiO}_{2}$ for Total Oxidation of Toluene and Polycyclic Aromatic Hydrocarbons (PAHs): Characterization and Catalytic Activity. Materials Chemistry and Physics, 142, 564-571. http://dx.doi.org/10.1016/j.matchemphys.2013.07.053 